\title{
Histochemical distribution of $\Delta^{5}-3 \beta$ - and $17 \beta$-hydroxysteroid dehydrogenases in hamster trophoblast
}

\author{
Chantal Legrand \\ Université P. et M. Curie, Laboratoire de Biologie de la Reproduction, 7 Quai Saint Bernard, \\ Paris, France
}

\begin{abstract}
Summary. The histochemical distribution of $\Delta^{5}-3 \beta$ - and $17 \beta$-hydroxysteroid dehydrogenases was demonstrated in hamster trophoblast between Days 8 and 15 of pregnancy. The $\Delta^{5}-3 \beta$-hydroxysteroid dehydrogenase activity in the ectoplacental trophoblast of 8-day embryos was demonstrated by use of $\Delta^{5}$-pregnenolone and dehydroepiandrosterone as substrates; between Days 11 and 15 , activity was demonstrated in the trophoblastic giant cells of the placenta and in the intra-arterial trophoblast cells when $\Delta^{5}$-pregnenolone was the substrate. Between Days 11 and $15,17 \beta$-hydroxysteroid activity was present in the spongiotrophoblast, labyrinth, placental giant cells and intra-arterial trophoblast cells, as shown by use of testosterone and oestradiol as substrates. Both enzymes were demonstrated in ectopic trophoblast cells, indicating that these activities are autonomous.
\end{abstract}

\section{Introduction}

The $\Delta^{5}-3 \beta$ - and $17 \beta$-hydroxysteroid dehydrogenases are known to be essential for the metabolism

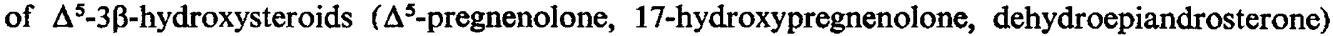
and $17 \beta$-hydroxysteroids (testosterone, oestradiol-17 $\beta$ ) during pregnancy. These enzymes have been detected in hamster embryos at 3-5 days post coitum (Dickmann \& Gupta, 1974) and at the 1- and 2-cell cleavage stages (Niimura \& Ishida, 1976). Many authors have described the histochemical distribution of $\Delta^{5}-3 \beta$ - and $17 \beta$-hydroxysteroid dehydrogenases in the trophoblast of rats (Deane, Rubin, Dricks, Lobel \& Leipsner, 1962; Deane \& Rubin, 1965; Botte, Materazzi \& Chieffi, 1966; Ferguson \& Christie, 1967; Schmidt, Wendler \& Gabler, 1970; Legrand \& Nguyen Son Hung, 1972; Legrand, 1975), mice (Botte, Tramontana \& Chieffi, 1968) and guinea-pigs (Ferguson \& Christie, 1967), but the hamster does not appear to have been investigated similarly.

\section{Materials and Methods}

Samples of conceptuses were removed from 16 pregnant hamsters (Mesocricetus auratus), 2 months old, on Days $8,11,13$ or 15 post coitum. Day 1 of pregnancy was the day on which spermatozoa were found in the vaginal smear. Embryos at 8 days p.c. were grafted into the testis of 6 cryptorchid male hamsters as previously described (Legrand \& Hernandez-Verdun, 1974) and removed 4 days later.

All samples were frozen in liquid nitrogen and $10 \mu \mathrm{m}$ sections were cut in a cryostat at $-18^{\circ} \mathrm{C}$. The sections were collected on glass cover-slips and placed in $0 \cdot 1 \mathrm{M}$-phosphate buffer, $\mathrm{pH} 7 \cdot 2$, to wash out any blood containing endogenous plasma steroids. The sections were incubated by the procedures of Deane et al. (1962), Baillie, Ferguson \& Hart (1966) and Botte et al. (1966) to demonstrate $\Delta^{5}-3 \beta$ - and $17 \beta$-hydroxysteroid dehydrogenases. The incubation medium was of $0.1 \mathrm{M}$-sodium phosphate buffer, pH 7.2, containing $0.06 \mathrm{~mm}-\mathrm{NAD} / 1,0.08 \mathrm{~mm}$-tetrazolium nitroblue $/ 1,0.9 \mathrm{~mm}$-nicotinamide/l and the specific substrate $(1.7 \mathrm{~mm} / \mathrm{l})$. Nicotinamide was added to prevent decomposition of NAD. The four substrates used were $\Delta^{5}$-pregneneolone, dehydroepiandrosterone, testosterone and oestradiol-17 $\beta$; they were dissolved in dimethyl-formamide before addition to the incubation medium. Control sections were incubated in the phosphate buffer with NAD, tetrazolium nitroblue, nicotinamide and dimethyl-formamide but without the specific substrate. 
After incubation at $37^{\circ} \mathrm{C}$ for $2 \mathrm{~h}$ the sections were fixed in formalin-alcohol and mounted on slides in water-soluble 'Apathy Syrup' for microscopic observation. About 30 sections, from material obtained from different pregnant animals, were assessed and compared for each reaction and each stage of pregnancy.

\section{Results}

The activities of the $\Delta^{5}-3 \beta$ - and $17 \beta$-hydroxysteroid dehydrogenases were demonstrated by the formation of diformazan granules in the cytoplasm after reduction of the tetrazolium salt (Levy, Deane \& Rubin, 1959). Enzyme activities were evaluated in the spongiotrophoblast, the labyrinth, the trophoblastic giant cells and in the intra-arterial trophoblast cells as well as in the intra-testicular grafts. The results are summarized in Table 1 . The reactions in all the controls were absolutely negative.

Table 1. Hydroxysteroid dehydrogenase (HSD) activities in tissues of the hamster placenta incubated with different substrates

\begin{tabular}{|c|c|c|c|c|}
\hline \multirow[b]{2}{*}{ Tissue } & \multicolumn{2}{|l|}{$\Delta^{5}-3 \beta-H S D$} & \multicolumn{2}{|c|}{ 17ß-HSD } \\
\hline & $\Delta^{5}$-Pregnenolone & DHA & Testosterone & Oestradiol-17ß \\
\hline \multicolumn{5}{|l|}{ Ectoplacental trophoblast } \\
\hline Day 8 & ++ & + & - & - \\
\hline \multicolumn{5}{|l|}{ Trophoblastic giant cells } \\
\hline Day 11 & ++ & - & ++ & ++ \\
\hline Day 13 & ++ & - & ++ & ++ \\
\hline Day 15 & ++ & - & +++ & $++t$ \\
\hline \multicolumn{5}{|l|}{ Spongiotrophoblast } \\
\hline Day 11 & - & - & + & + \\
\hline Day 13 & - & - & + & + \\
\hline Day 15 & - & - & + & + \\
\hline \multicolumn{5}{|l|}{ Labyrinth } \\
\hline Day 11 & - & - & + & + \\
\hline Day 13 & - & - & + & + \\
\hline Day 15 & - & - & + & ++ \\
\hline \multicolumn{5}{|l|}{ Intra-arterial trophoblast } \\
\hline Day 11 & + & - & $+H$ & $H+$ \\
\hline Day 13 & + & - & ++ & $+1+$ \\
\hline Day 15 & + & - & +++ & $+1+$ \\
\hline \multicolumn{5}{|l|}{ In testicular grafts } \\
\hline Intra-arterial trophoblast & + & - & +++ & +++ \\
\hline Trophoblastic giant cells & ++ & - & ++ & ++ \\
\hline
\end{tabular}

- , Absent; + , moderate; + , intense; +++ , very intense.

\section{EXPLANATION OF PLATE}

Demonstration of hydroxysteroid dehydrogenases (HSD) in the placental tissues of the hamster.

Fig. 1. $17 \beta-H S D$ in trophoblastic giant cells at Day 13 of pregnancy. Substrate, oestradiol-17 $\beta . \times 330$.

Fig. 2. $\Delta^{5}-3 \beta-H S D$ in trophoblastic giant cells at Day 13 of pregnancy. Substrate, $\Delta^{5}$-pregnenolone. $\times 330$.

Fig. 3. $17 \beta-H S D$ in the placental labyrinth at Day 15 of pregnancy. Substrate, oestradiol-17ß. $\times 330$.

Fig. 4. $17 \beta-H S D$ in the spongy zone of the placenta at Day 11 of pregnancy. Substrate, oestradiol-17ß. $\times 330$.

Fig. 5. $17 \beta$-HSD in intra-arterial trophoblast cells of the mesometrial arteries at Day 11 of pregnancy. Substrate, testosterone. $\times 330$.

Fig. 6. 17 $\beta$-HSD in intra-arterial trophoblast cells migrating along the testicular arteries. Substrate, oestradiol-17ß. $\times 470$. 


\section{PLATE 1}

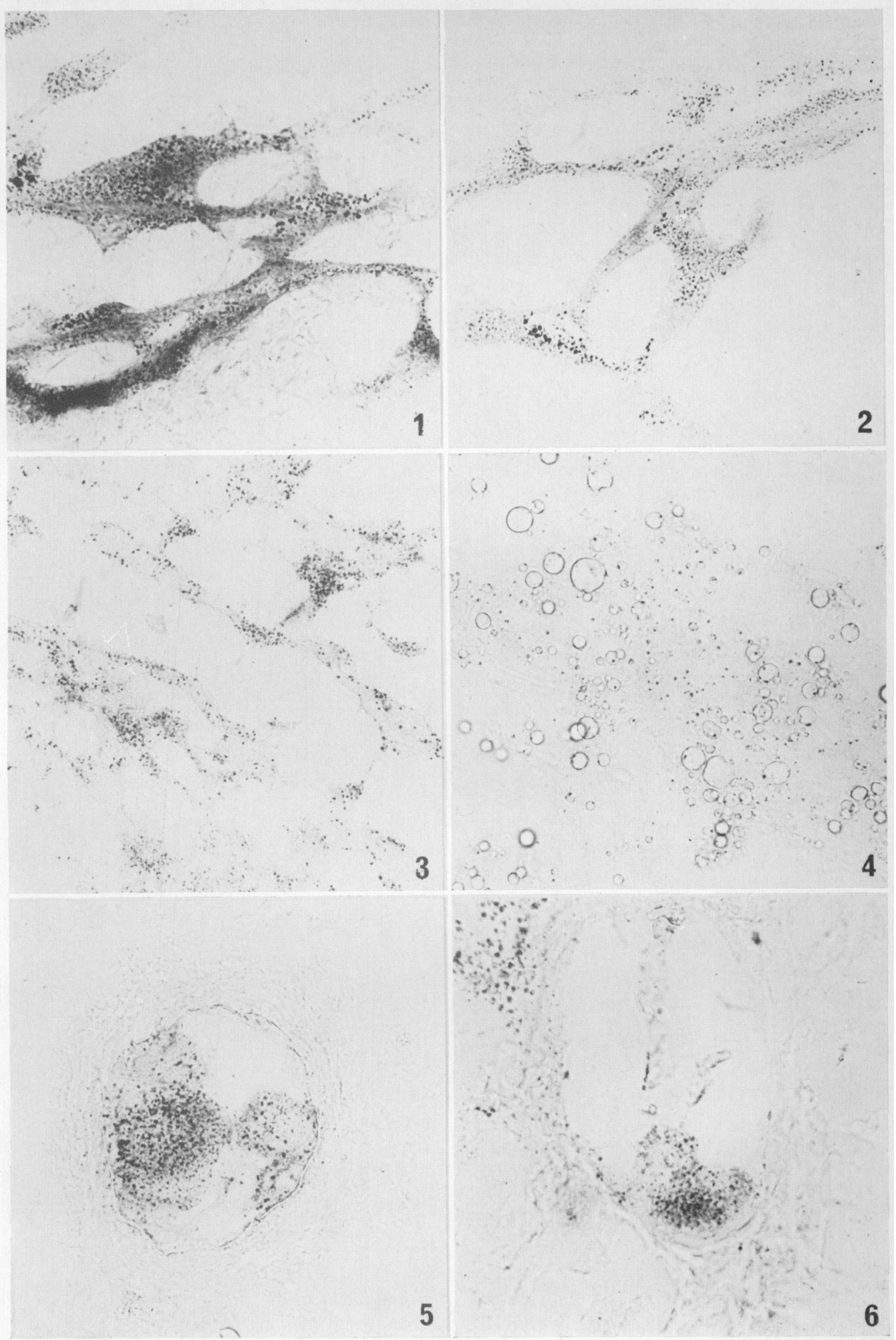


At Day 8 of pregnancy there were no histochemically demonstrable enzymes in the ectoplacental trophoblast cells when testosterone and oestradiol-17 $\beta$ were used as substrates. Between Days 11 and $15,17 \beta$-hydroxysteroid dehydrogenase was present in the various trophoblast tissues of the placenta (Pl. 1, Figs 1, 3 and 4) and was also active in the intra-arterial trophoblast cells which invade the mesometrial arteries of the pregnant uterus (Pl. 1, Fig. 5).

On the 8th day of pregnancy, a moderate $\Delta^{5}-3 \beta$-hydroxysteroid dehydrogenase activity was observed in the ectoplacental cone when dehydroepiandrosterone was used as a substrate. This activity was not present between Days 11 and 15 but when $\Delta^{5}$-pregnenolone was used as substrate enzymes were demonstrated in the trophoblastic giant cells (PI. 1, Fig. 2) and in intra-arterial trophoblast cells.

The distribution pattern of the enzymes in the trophoblastic giant cells (differentiated in the haemorrhagic nodule) and in intra-arterial trophoblast cells (migrating along testicular arteries; Pl. 1, Fig. 6) appeared similar to that observed in the pregnant uterus at the equivalent stage of gestation.

\section{Discussion}

It has been shown that $\Delta^{5}-3 \beta$-hydroxysteroid dehydrogenase remains active at Day 8 post coitum in some ectoplacental cells when dehydroepiandrosterone and $\Delta^{5}$-pregnenolone are used as substrates. Later, 11 to 15 days post coitum (i.e. the time of placental morphogenesis: Carpenter, 1975), the placental giant cells and intra-arterial trophoblast cells are able to synthesize progesterone from $\Delta^{5}$-pregnenolone but are no longer able to convert dehydroepiandrosterone into androstenedione. This observation indicates a metabolic pathway in hamster trophoblast which differs from that described for the mouse and rat. The trophoblastic giant cells and labyrinth in the rat and mouse, and the intra-arterial trophoblast cells in the rat, show an active metabolism of dehydroepiandrosterone during the second half of pregnancy (Botte et al., 1968; Legrand, 1975; Okker-Reitsma, 1976). In the pregnant hamster, the conversion of dehydroepiandrosterone into androstenedione is effected by the ovaries between Days 11 and 15 because $\Delta^{5}-3 \beta$-hydroxysteroid dehydrogenase remains intensively active when dehydroepiandrosterone is used as the substrate (C. Legrand, unpublished results). The activity of $17 \beta$-hydroxysteroid dehydrogenase appears much later and is present in all tissues derived from trophoblast, indicating that these tissues are able to effect the reversible conversion of testosterone into androstenedione and of oestradiol-17 $\beta$ into oestrone.

The distribution patterns of $\Delta^{5}-3 \beta$ - and $17 \beta$-hydroxysteroid dehydrogenases in the ectopic trophoblast and trophoblast tissues in utero of the hamster agrees with previous findings of Dickmann \& Dey (1974) and Marcal, Chew, Salomon \& Sherman (1975), who suggest that hydroxysteroid dehydrogenase activities in the rat blastocyst and placenta are autonomous and do not depend on maternal hormonal control. This is also the case in the mouse, because Chew \& Sherman (1975) have shown that $3 \beta$-hydroxysteroid activity of the trophoblast "can be monitored both in vitro and in vivo".

\section{References}

Baillie, A.H., Ferguson, M.M. \& Hart, D. McK. (1966) Developments in Steroid Histochemistry. Academic Press, London.

Botte, V., Materazzi, G. \& Chiefri, G. (1966) Histochemical distribution of $3 \beta$-hydroxysteroid dehydrogenase and $17 \alpha$ and $17 \beta$-hydroxysteroid dehydrogenases in the placenta and foetal membranes of the rat. J. Endocr. 34, 179-183.

Botre, V., Tramontana, S. \& Chieffi, G. (1968) Histochemical distribution of some hydroxysteroid dehydrogenases in the placenta, foetal membranes and uterine mucosa of the mouse. J. Endocr. 40, 189-194.
CARPENTER, J. S. (1975) Ultrastructural observations on the maturation of the placental labyrinth of the golden hamster (Days 10 to 16 of gestation), Am. J. Anat. 143, 315-348.

Chew, N.J. \& Sherman, M.I. (1975) Biochemistry of differentiation of mouse trophoblast : $\Delta^{5}, 3 \beta$-hydroxysteroid dehydrogenase. Biol. Reprod. 12, 351-360.

DEANE; H.W. \& RUBIN, B.L. (1965) Identification and control of cells that synthetise steroid hormones in the adrenal glands, gonads and placentae of various mammalian species. Archs Anat. microsc. Morph. exp. 54, 49-66. 
Deane, H.W., Rubin, B.L., Dricks, E.C., Lobel, B.L. \& LEIPSNER, G. (1962) Trophoblastic giant cells in placenta of rats and mice and their probable role in steroid hormone production. Endocrinology 70, 407-419.

DickmanN, Z. \& DeY, S.K. (1974) Evidence that $\Delta^{5}-3 \beta$-hydroxysteroid dehydrogenase activity in rat blastocyst is autonomous. J. Endocr. 61, 513-514.

DickmanN, Z. \& GuPTA, J.S. (1974) $\Delta^{5}-3 \beta-H y d r o x y-$ steroid dehydrogenase and estradiol-17 $\beta$ hydroxysteroid dehydrogenase activity in preimplantation hamster embryos. Devl Biol. 40, 196-198.

Ferguson, M.M. \& Christie, G.A. (1967) Distribution of hydroxysteroid dehydrogenases in the placentae and foetal membranes of various mammals. $J$. Endocr.38, 291-306.

LEGRAND, C. (1975) La fonction stéroidogène du trophoblaste intra-artériel chez la Ratte. Eur. $J$. Gynec. Obstet., Biol. Reprod. 4, 1017-1035.

Legrand, C. \& Hernandez-Verdun, D. (1974) Données autoradiographiques sur la différenciation du trophoblaste après transplantation intra-testiculaire d'embryons chez le Hamster doré. Cytobiologie 8, 457-467.
Legrand, C. \& Nguyen Son Hung (1972) Mise en évidence d'une activité stéroidodeshydrogénasique dans le trophoblaste intra-artériel chez la Ratte gestante. C. r. hebd. Séanc. Acad. Sci., Paris 275, 1513-1515.

Levy, H., Deane, H.W. \& Rubin, B.L. (1959) Visualization of steroid $\Delta^{5}-3 \beta$-ol-dehydrogenase activity in tissues of intact hypophysectomized rats. Endocrinology 65, 932-943.

Marcal, J.M., Chew, N.J., Salomon, D.S. \& Sherman,

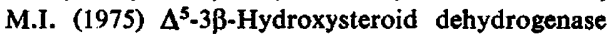
activities in rat trophoblast and ovary during preg. nancy. Endocrinology 96, 1270-1279.

Nimura, S. \& IsHIDA, K. (1976) Histochemical studies of $\Delta^{5}-3 \beta-, 20 \alpha$ - and $20 \beta$-hydroxysteroid dehydrogenases and possible progestagen production in hamster eggs. J. Reprod. Fert. 48, 275-278.

OKKER-ReITSMA, G.H. (1976) Metabolism of 3H. dehydroepiandrosterone by mouse placental tissue in vitro. Proc. K. ned Aked. Wet. 79, 290-298.

Schmidt, W., Wendler, D. \& Gabler, W. (1970) Aktivität und Lokalisation Verschiedener steroiddehydrogenasen (St DH) während der Plazentation der Ratte. Acta histochem. 38, 318-326.

Received 21 February 1977 